\title{
Capaian dan Proyeksi Kondisi Hukum Indonesia
}

\author{
Mahfud MD \\ Mahkamah Konstitusi Jl. Merdeka Barat No.6 Jakarta \\ mahfud@mahfudmd.com
}

\begin{abstract}
To review the achievements of legal development during reformation era, shall be a parameter to be a foundation; which are some causes that led to the need for legal reform. In other word, it need to be identified what were the problems of legal development during the New Order era which in turns pushed to the rise of legal reform subsequently after political reform in 1998. There were problems addressed by legal reform, such as, the amendment of 1945 Indonesian Constitution, judicial reform through the amendment of Judicial Power Act, the inception of Corruption Eradication Commission, and also the inception of some new bodies which are considered to be helpful for the purpose of an effective legal enforcement and the maintenance of democracy.
\end{abstract}

Keywords: : achievement, projection, current Indonesian legal system

\section{Pendahuluan}

Reformasi hukum telah dijadikan sebagai salah satu agenda utama di era reformasi. Hal itu dilandasi oleh kesadaran bahwa sistem hukum yang dikembangkan selama masa Orde Baru bersifat represif dan hanya menjadi alat legitimasi bagi kekuasaan yang korup. Hal itu secara tegas dituangkan dalam Ketetapan MPR Nomor X/MPR/1998 tentang PokokPokok Reformasi Pembangunan Dalam Rangka Penyelamatan dan Normalisasi Kehidupan Nasional Sebagai Haluan Negara. Ketetapan tersebut menyatakan bahwa kondisi umum hukum di Indonesia telah memberikan peluang terjadinya praktik-praktik korupsi, kolusi, dan nepotisme serta memuncak pada penyimpangan berupa penafsiran yang hanya sesuai dengan selera penguasa. Telah terjadi penyalahgunaan wewenang, pelecehan hukum, pengabaian rasa keadilan, kurangnya 
perlindungan dan kepastian hukum bagi masyarakat. Bahkan ditegaskan pula bahwa penegakan hukum belum memberi rasa keadilan dan kepastian hukum pada kasus-kasus yang menghadapkan pemerintahan atau pihak yang kuat dengan rakyat, sehingga menempatkan rakyat pada posisi yang lemah. ${ }^{1}$

Dalam proses pembangunan hukum di era reformasi tentu diperlukan politik hukum, yaitu arah kebijakan hukum yang dibuat secara resmi oleh negara. Sesuai dengan konfigurasi politik era refomasi yang demokratis tentu pembangunan hukum harus menghasilkan hukum yang responsif. Hukum ditempatkan sebagai alat untuk mencapai tujuan negara sehingga pembuatan hukum baru atau pencabutan hukum lama harus dijadikan sebagai langkah untuk mencapai tujuan negara. Meskipun hukum dikatakan sebagai "alat", di dalamnya terletak hakikat supremasi hukum. Hukum bukan semata-mata alat rekayasa politik atau instrumen untuk mendukung kemauan penguasa, tetapi hukum menjadi sentral pengarah dan pedoman upaya mencapai tujuan negara. Di sinilah makna supremasi hukum. $^{2}$

\section{Kaidah Penuntun}

Untuk merumuskan politik hukum, setiap negara harus berpijak kepada sistem hukum yang dianut, yang bagi bangsa Indonesia adalah sistem hukum Pancasila. Istilah sistem hukum Pancasila akhir-akhir ini memang tidak banyak dibahas dan dibicarakan, padahal sistem hukum Pancasila adalah sistem yang berakar dari budaya bangsa sebagai kaidah penuntun arah pembangunan hukum untuk mencapai tujuan nasional. Pancasila adalah nilai-nilai dasar sebagai rambu-rambu pembangunan hukum nasional. Nilai-nilai dasar tersebut melahirkan empat kaidah penuntun hukum yang harus dipedomani dalam pembangunan hukum. ${ }^{3}$ Pertama, hukum nasional harus dapat menjaga integrasi (keutuhan

\footnotetext{
${ }^{1}$ Kondisi Umum Bidang Hukum, Pokok-Pokok Reformasi Pembangunan Dalam Rangka Penyelamatan dan Normalisasi Kehidupan Nasional sebagai haluan Negara. Ketetapan MPR Nomor X/MPR/1998.

${ }^{2}$ Moh. Mahfud MD., “Refleksi Fakultas Hukum UGM Terhadap Kondisi Hukum Indonesia, Makalah yang dipresentasikan di Fakultas Hukum UGM, Yogyakarta, 16 Pebruari 2009.

${ }^{3}$ Moh. Mahfud MD.,Perdebatan Hukum Tata Negara Pasca Amandemen Konstitusi, Jakarta, LP3ES, 2007, hlm. 48-49.
} 
kesatuan) baik ideologi maupun teritori sesuai dengan tujuan "melindungi segenap bangsa dan seluruh tumpah darah Indonesia". Harus dicegah munculnya produk hukum yang berpotensi memecah-belah keutuhan bangsa dan negara Indonesia.

Kedua, hukum nasional harus dibangun secara demokratis dan nomokratis dalam arti harus mengundang partisipasi dan menyerap aspirasi masyarakat luas melalui mekanisme yang fair, transparan dan akuntabel.

Ketiga, hukum nasional harus mampu menciptakan keadilan sosial dalam arti harus mampu memperpendek jurang antara yang kuat dan yang lemah serta memberi proteksi khusus terhadap golongan yang lemah dalam berhadapan dengan golongan yang kuat baik dari luar maupun dari dalam negeri sendiri. Tanpa proteksi khusus dari hukum, golongan yang lemah pasti akan selalu kalah jika dilepaskan bersaing atau bertarung secara bebas dengan golongan kuat.

Keempat, hukum harus menjamin toleransi beragama yang berkeadaban antara pemeluknya. Tidak boleh ada pengistimewaan perlakuan terhadap agama hanya karena didasarkan pada besar dan kecilnya jumlah pemeluknya. Negara boleh mengatur kehidupan beragama sebatas pada menjaga ketertiban agar tidak terjadi konflik serta menfasilitasi agar setiap orang dapat melaksanakan ajaran agamanya dengan bebas tanpa mengganggu atau diganggu oleh oang lain.

\section{Politik Hukum di Era Reformasi}

Salah satu keberhasilan era reformasi adalah perubahan UUD 1945. Walaupun masih memiliki kelemahan, UUD 1945 pasca perubahan telah meletakkan dasar-dasar kehidupan bernegara dan pembangunan hukum yang demokratis. Terlepas dari masih adanya pro dan kontra terhadap perubahan tersebut, UUD 1945 pasca perubahan harus ditempatkan sebagai hukum tertinggi yang sah berlaku karena dibuat oleh lembaga yang berwenang yaitu MPR melalui prosedur hukum yang sah pula.

Sebagai hukum tertinggi, di dalam UUD 1945 dimuat arah kebijakan hukum yang harus dijalankan sesuai dengan tujuan nasional yang hendak dicapai dan berdasarkan pada Pancasila yang termaktub dalam Pembukaan UUD 1945. Arah kebijakan hukum tersebut meliputi segala aspek kehidupan berbangsa, baik di bidang politik, ekonomi, maupun sosial budaya. Sebagai prinsip utama politik hukum berdasarkan UUD 1945 adalah prinsip negara hukum dan supremasi konstitusi. 
Pasal 1 ayat (3) UUD 1945 menyatakan "Negara Indonesai adalah negara hukum". Konsep negara hukum yang dulu dikesankan menganut konsep rechtsstaat dinetralkan menjadi negara hukum saja, tanpa label rechtsstaat. Dengan demikian konsep negara hukum yang dianut UUD 1945 diperoleh baik dari rechtsstaat maupun the rule of law, bahkan sistem hukum lainnya yang menyatu (integratif) dan implementasinya disesuaikan dengan tuntutan perkembangan. ${ }^{4}$

Konsep negara hukum Indonesia menerima prinsip kepastian hukum yang menjadi hal utama dalam konsep rechtsstaat, sekaligus juga menerima prinsip rasa keadilan dalam the rule of law. Bahkan, negara hukum Indonesia juga menerima nilai spiritual dari hukum agama. Hukum tertulis dan segala ketentuan proseduralnya (rechtsstaat) diterima tetapi harus diletakkan dalam rangka menegakkan keadilan (the rule of law). Ketentuan tertulis yang menghalangi keadilan dapat ditinggalkan. Hal ini ditegaskan dalam ketentuan Pasal 24 ayat (1) UUD 1945 yang menyatakan bahwa fungsi kekuasaan kehakiman adalah untuk menegakkan hukum dan keadilan, serta Pasal 28D ayat (1) tentang hak memperoleh kepastian hukum dan Pasal 28H bahwa hukum harus dibangun berdasarkan keadilan kemanfaatan.

Dianutnya prinsip negara hukum juga dilakukan dengan penegasan supremasi konstitusi. Hal itu tertuang dalam Pasal 1 ayat (2) UUD 1945 yang menyatakan bahwa kedaulatan berada di tangan rakyat dan dilaksanakan menurut ketentuan Undang-Undang Dasar. Dengan demikian, pelaksanaan kekuasaan tertinggi dalam negara, yaitu kedaulatan, baik oleh lembaga negara maupun oleh warga negara harus dilakukan sesuai dengan ketentuan UUD 1945. Hal itu juga menegaskan kedudukan UUD 1945 sebagai hukum tertinggi yang mengatur pelaksanaan kedaulatan.

Di sisi lain, salah satu perubahan mendasar dalam UUD 1945 adalah orientasi pengaturan tidak lagi lebih banyak kepada organisasi negara, tetapi juga memberikan jaminan dan perlindungan kepada hak asasi manusia dan hak konstitusional warga negara. Pada masa lalu, UUD 1945 sebelum perubahan hanya mengatur HAM secara sumir yang pelaksanaannya didistribusikan kepada lembaga legislatif yang ternyata

\footnotetext{
${ }^{4}$ Baca lebih lanjut dalam Moh. Mahfud MD., Hukum, Moral, dan Politik, Materi Stadium General untuk Matrikulasi Program Doktor Bidang Ilmu Hukum di Universitas Diponegoro, Semarang, 23 Agustus 2008, Hlm. 33.
} 
dalam ketentuan UU hanya dijadikan sebagai residu dari kekuasaan. Itulah sebabnya pada masa Orde Lama dan Orde Baru selalu terjadi pelanggaran HAM dan kekerasan yang dilegitimasikan oleh UU. ${ }^{5}$

Saat ini masalah HAM serta hak konstitusional warga negara diatur paling tidak dalam enam bab, yaitu dalam Bab Warga Negara dan Penduduk, Bab Hak Asasi Manusia, Bab Agama, Bab Pertahanan dan Keamanan Negara, bab Pendidikan dan kebudayaan, serta Bab Perekonomian Nasional dan Kesejahteraan Sosial. Sedangkan khusus untuk HAM diatur tersendiri dalam 10 pasal yang terdiri atas 26 ayat. Oleh karena itu pelanggaran HAM tidak dapat lagi dilakukan dengan mudah karena adanya jaminan serta tanggung jawab negara, terutama pemerintah, dalam perlindungan, penghormatan, dan pemajuan HAM.

Politik hukum dalam UUD 1945 selanjutnya dijabarkan dalam kebijakan yang menentukan arah pembangunan hukum. Pada era reformasi, produk hukum yang menentukan arah kebijakan hukum tersebut adalah Ketetapan MPR Nomor IV/MPR/1999 tentang Garis-Garis Besar Haluan Negara Tahun 1999 - 2004. Selanjutnya, sebagai konsekuensi pemilihan Presiden secara langsung dan tidak dikenalnya lagi Ketetapan MPR dalam sistem hukum baru, tidak ada lagi Garis-garis Besar Haluan Negara. Pada periode selanjutnya, politik hukum termuat dalam Rencana Pembangunan Jangka Panjang dan Rencana Pembangunan Jangka Menengah.

Perumusan politik hukum selalu meliputi tiga komponen utama, yaitu substansi, struktur, dan kultur hukum. Dalam hal substansi hukum, GBHN 1999 - 2004 menentukan arah kebijakan hukum sebagai berikut: (1) Menata sistem hukum nasional yang menyeluruh dan terpadu dengan mengakui dan menghormati hukum agama dan hukum adat serta memperbaharui perundang-undangan warisan kolonial dan hukum nasional yang diskriminatif, termasuk keadilan gender dan ketidaksesuaiannya dengan tuntutan reformasi melalui program legislasi; (2) Melanjutkan ratifikasi konvensi internasional, terutama yang berkaitan dengan hak asasi manusia sesuai dengan kebutuhan dan kepentingan bangsa dalam bentuk undang-undang; (3) Mengembangkan peraturan perundangundangan yang mendukung kegiatan perekonomian dalam menghadapi era perdagangan bebas tanpa merugikan kepentingan nasional.

${ }^{5}$ Baca lebih lanjut dalam Moh. Mahfud MD, Membangun Politik Hukum, Menegakkan Konstitusi, LP3ES, Jakarta, 2006, Hlm. 143-154. 
Terkait dengan struktur hukum, termasuk penegakan hukum, arahan kebijakan dalam GBHN 1999 - 2004 adalah sebagai berikut: (1) Menegakkan hukum secara konsisten untuk lebih menjamin kepastian hukum, keadilan dan kebenaran, supremasi hukum, serta menghargai hak asasi manusia; (2) Meningkatkan integritas moral dan keprofesionalan aparat penegak hukum, termasuk Kepolisian Nasional Republik Indonesia, untuk menumbuhkan kepercayaan masyarakat dengan meningkatkan kesejahteraan, dukungan sarana dan prasarana hukum, pendidikan, serta pengawasan yang efektif. (3) Mewujudkan lembaga peradilan yang mandiri dan bebas dari pengaruh penguasa dan pihak manapun; (4) Menyelesaikan proses peradilan secara cepat, mudah, murah dan terbuka serta bebas korupsi, kolusi, dan nepotisme dengan tetap menjunjung tinggi asas keadilan dan kebenaran; (5) Menyelesaikan berbagai proses peradilan terhadap pelanggaran hukum dan hak asasi manusia yang belum ditangani secara tuntas.

Sedangkan untuk budaya hukum GBHN 1999 - 2004 merumuskan arah kebijakan sebagai berikut: (1) Mengembangkan budaya hukum di semua lapisan masyarakat untuk terciptanya kesadaran dan kepatuhan hukum dalam kerangka supremasi hukum dan tegaknya negara hukum; (2) Meningkatkan pemahaman dan penyadaran, serta meningkatkan perlindungan, penghormatan, dan penegakan hak asasi manusia dalam seluruh aspek kehidupan.

Di dalam Rencana Pembangunan Jangka Panjang Nasional Tahun 2005 - 20256 pembangunan hukum diarahkan pada makin terwujudnya sistem hukum nasional yang mantap bersumber pada Pancasila dan UUD 1945, yang mencakup pembangunan materi hukum, struktur hukum termasuk aparat hukum, sarana dan prasarana hukum; perwujudan masyarakat yang mempunyai kesadaran dan budaya hukum yang tinggi dalam rangka mewujudkan negara hukum; serta penciptaan kehidupan masyarakat yang adil dan demokratis. Pembangunan hukum dilaksanakan melalui pembaruan hukum dengan tetap memperhatikan kemajemukan tatanan hukum yang berlaku dan pengaruh globalisasi sebagai upaya untuk meningkatkan kepastian dan perlindungan hukum, penegakan hukum dan HAM, kesadaran hukum, serta pelayanan hukum yang

\footnotetext{
${ }^{6}$ Undang-Undang Nomor 17 Tahun 2007 tentang Rencana Pembangunan Jangka Panjang Nasional Tahun 2005 - 2025. Lembaga Negara RI Tahun 2007 Nomor 33. Tambahan Lembaga Negara RI Nomor 4700.
} 
berintikan keadilan dan kebenaran, ketertiban, dan kesejahteraan dalam rangka pembangunan nasional akan makin tertib dan teratur sehingga penyelenggaraan pembangunan nasional akan makin lancar. Selengkapnya, arah pembangunan bidang hukum adalah sebagai berikut.

Pembangunan materi hukum diarahkan untuk melanjutkan pembaruan produk hukum untuk menggantikan peraturan perundangundangan warisan kolonial yang mencerminkan nilai-nilai sosial dan kepentingan masyarakat Indonesia serta mampu mendorong tumbuhnya penyelenggaraan pemerintahan dan pembangunan nasional yang bersumber pada Panca dan UUD 1945. Pembangunan materi hukum mencakup tahapan penerapan hukum, pembentukan hukum, penelitian dan pengembangan hukum. Di sisi lain, perundang-undangan yang baru juga harus mampu mengisi kekurangan/kekosongan hukum sebagai pengarah dinamika lingkungan strategis yang sangat cepat berubah.

Perencanaan hukum sebagai bagian dari pembangunan materi hukum harus diselenggarakan dengan memberikan berbagai aspek yang mempengaruhi, baik di dalam masyarakat sendiri maupun dalam pergaulan masyarakat internasional yang dilakukan secara terpadu dan meliputi semua bidang pembangunan sehingga produk hukum yang dihasilkan dapat memenuhi kebutuhan kehidupan masyarakat, bangsa, dan negara serta dapat mengantisipasi perkembangan zaman. Pembentukan hukum diselenggarakan melalui proses terpadu dan demokratis sehingga menghasilkan produk hukum beserta peraturan pelaksanaan yang dapat diaplikasikan secara efektif dengan didukung oleh penelitian dan pengembangan hukum yang didasarkan pada aspirasi dan kebutuhan masyarakat. Penelitian dan pengembangan hukum diarahkan pada semua aspek kehidupan sehingga hukum nasional selalu dapat mengikuti perkembangan dan dinamika pembangunan yang sesuai dengan aspirasi masyarakat, baik kebutuhan saat ini maupun masa depan.

Pembangunan struktural hukum diarahkan untuk memantapkan dan mengefektifkan berbagai organisasi dan lembaga hukum, profesi hukum, dan badan peradilan sehingga aparatur hukum mampu melaksanakan tugas dan kewajibannya secara profesional. Kualitas dan kemampuan aparatur hukum dikembangkan melalui peningkatan kualitas dan profesionalisme melalui sistem pendidikan dan pelatihan dengan kurikulum yang akomodatif terhadap setiap perkembangan pembangunan serta pengembangan sikap aparatur hukum yang menjunjung tinggi kejujuran, kebenaran, keterbukaan dan keadilan, bebas dari korupsi, 
kolusi, dan nepotisme serta bertanggungjawab dalam bentuk perilaku yang teladan. Aparatur hukum dalam melaksanakan tugas dan kewajibannya secara profesional perlu didukung oleh sarana dan prasarana hukum yang memadai serta diperbaiki kesejahteraannya agar di dalam melaksanakan tugas dan kewajibannya aparatur hukum dapat berjalan dengan baik dan terhindar dari pengaruh dan intervensi pihakpihak dalam bentuk korupsi, kolusi, dan nepotisme.

Penerapan dan penegakan hukum dan hak asasi manusia dilaksanakan secara tegas, lugas, profesional dan tidak diskriminatif dengan tetap berdasarkan pada penghormatan terhadap hak-hak asasi manusia, keadilan, dan kebenaran, terutama dalam penyelidikan, penyidikan, dan persidangan yang transparan dan terbuka dalam rangka mewujudkan tertib sosial dan disiplin sosial sehingga mendukung pembangunan serta memantapkan stabilitas nasional yang mantap dan dinamis. Penegakan hukum dan hak asasi manusia dilakukan terhadap berbagai tindak pidana, terutama yang akibatnya dirasakan langsung oleh masyarakat luas, antara lain tindak pidana korupsi, kerusakan lingkungan, dan penyalahgunaan narkotika. Dalam rangka menjaga keutuhan wilayah Negara Kesatuahn Republik Indonesia, penegakan hukum di laut secara terus-menerus harus ditingkatkan sesuai dengan kewenangan yang diatur dalam perundang-undangan nasional dan hukum internasional.

Pemantapan lembaga peradilan sebagai implikasi satu atap dengan lembaga Mahkamah Agung secara terus-menerus melakukan pengembangan lembaga peradilan; peningkatan kualitas dan profesionalisme hakim pada semua lingkungan peradilan; dukungan serta perbaikan sarana dan prasarana pada semua lingkungan peradilan sehingga dapat mengembalikan kepercayaan masyarakat terhadap citra lembaga peradilan sebagai benteng terakhir pencari keadilan.

Peningkatan perwujudan masyarakat yang mempunyai kesadaran hukum yang tinggi terus ditingkatkan dengan lebih memberikan akses terhadap segala informasi yang dibutuhkan oleh masyarakat, dan akses kepada masyarakat terhadap pelibatan dalam berbagai proses pengambilan keputusan pelaksanaan pembangunan nasional sehingga setiap anggota masyarakat menyadari dan menghayati hak dan kewajibannya sebagai warga negara. Akibatnya, akan terbentuk perilaku warga negara Indonesia yang mempunyai rasa memiliki dan taat hukum. Peningkatan perwujudan masyarakat yang mempunyai kesadaran hukum yang tinggi harus didukung oleh pelayanan dan bantuan hukum dengan 
biaya yang terjangkau, proses yang tidak berbelit, dan penetapan putusan yang mencerminkan rasa keadilan.

Rumusan arah kebijakan hukum dalam RPJP 2005 - 2025 tersebut di atas tidak hanya menentukan materi pembangunan hukum, baik di bidang substansi, struktur, maupun kultur dan sarana, tetapi juga memberikan pokok-pokok strategi yang harus dilakukan untuk menjalankan materi politik hukum. Bahkan juga disebut hal-hal yang perlu mendapat perhatian khusus seperti upaya pengembangan lembaga peradilan di bawah MA untuk mengembalikan kepercayaan masyarakat terhadap citra lembaga peradilan sebagai benteng terakhir pencari keadilan.

\section{Capaian dan Proyeksi}

Untuk menilai capaian yang telah diraih pembangunan hukum di era reformasi politik hukum sebagai arah kebijakan pembangunan hukum harus dijadikan sebagai ukuran. Hal itu tentu memerlukan proses pengkajian dan penelitian yang mendalam serta meliputi berbagai bidang hukum dan berbagai aspek pembangunan hukum. Namun demikian, tentu kita bisa mengidentifikasi capaian tersebut dari pengamatan secara umum terhadap fenomena-fenomena yang mengemuka dan dapat dilihat oleh semua orang.

Di bidang substansi hukum, dari sisi kuantitatif pada 1999 hingga 2004 telah dibuat 175 UU dan pada masa 2004 hingga 2008 telah dibuat $129 \mathrm{UU}$, sehingga pada era reformasi secara keseluruhan telah terdapat 304 UU. Banyaknya UU yang telah disahkan itu paling tidak telah menggantikan beberapa peraturan warisan kolonial dan menyesuaikan peraturan perundang-undangan dengan perkembangan masyarakat. Namun dari 304 UU yang telah berhasil dibuat itu ternyata terdapat 118 UU yang merupakan UU pembentukan daerah dan UU pembentukan pengadilan di daerah. Jumlah tersebut belum termasuk UU pengesahan konvensi atau perjanjian internasional. Dengan demikian sesungguhnya jumlah UU yang substansinya benar-benar norma hukum jauh lebih sedikit dari pada UU yang telah disahkan DPR dan Presiden.

Di sisi lain, dari sisi kualitas banyak UU yang dipertanyakan konstitusionalitasnya. Hal itu dapat dilihat dari UU yang dimohonkan pengajuan kepada Mahkamah Konstitusi (MK) sebanyak 73 UU. Dari jumlah UU tersebut hanya 4 UU yang dibuat sebelum tahun 1999. MK hingga saat ini telah membatalkan 4 UU secara keseluruhan, dan 
membatalkan ketentuan tertentu yang ada dalam 25 UU. ${ }^{7}$ Bahkan, menurut penelitian Elsa, dari 129 UU yang dibuat pada periode 2004 2008 terdapat 111 UU yang bertentangan dengan HAM. ${ }^{8}$

Di masa mendatang, masih menjadi agenda penting agar sesuai dengan UUD 1945, terutama kaidah penuntun berdasarkan nilai-nilai Pancasila. Di bidang ekonomi, saat ini banyak peraturan hukum yang dinilai sudah tidak sesuai lagi dengan karakteristik ekonomi Pancasila. Proses liberalisasi ekonomi dan perdagangan melalui berbagai UU dipandang telah menggeser Indonesia menjadi negara ajang kelompok kapitalis. Sementara itu hukum yang mengatur aktivitas politik dan kenegaraan masih mencari bentuk dari berbagai sistem yang ada serta perlu penyesuaian dengan karakteristik masyrakat Indonesia.

Perkembangan hukum ke depan juga akan merambah kehidupan sosial budaya masyarakat. Akan semakin sering terjadi tarik menarik kebebasan individu dalam berekspresi dan kepentingan ketertiban umum seperti yang terjadi pada saat akan disahkannya UU Pornografi. Tarikmenarik tersebut juga akan memasuki wilayah kebebasan beragama sehingga memunculkan kembali perdebatan antara negara dan agama.

Di sektor struktur hukum, keberhasilan reformasi dapat dilihat dari pembentukan lembaga-lembaga baru di bidang hukum, baik yang diamanatkan oleh UUD 1945 maupun oleh UU tertentu. Beberapa lembaga baru tersebut telah berhasil menjadi ikon perubahan penegakan hukum yang diakui oleh publik.

Namun demikian, perubahan sepenuhnya berhasil dilakukan terhadap aparat penegak hukum dan lembaga peradilan. Walaupun telah menjadi sorotan publik selama 10 tahun reformasi, praktik mafia peradilan tetap terjadi. Upaya reformasi peradilan yang telah dilakukan melalui pembentukan Komisi Yudisial dan peningkatan integritas dan kualitas hakim belum mampu mengembalikan kepercayaan masyarakat. Hal inilah yang menjadi agenda penting di masa yang akan datang. Reformasi peradilan dan penegakan hukum juga sudah harus menyentuh mekanisme penyelesaian perkara dan administrasi justisial di lembaga peradilan yang menentukan kinerja lembaga peradilan.

${ }^{7}$ Lihat buku Lima Tahun Menegakkan Konstitusi, Jakarta (Mahkamah Konstitusi Republik Indonesia, 2008).

${ }^{8}$ http:/ / www.inilah.com/berita/politik/2008/12/04/66492/111-uu-tidakpro-ham/. 
Di sektor kultur hukum, era komunikasi dan informasi telah meningkatkan kesadaran hukum masyarakat. Apalagi proses demokratisasi telah mendorong keterbukaan informasi dan kebebasan individu. Walaupun pemerintah dan aparat penegak hukum belum mampu menyediakan informasi hukum yang memadai, masyarakat dapat memperoleh informasi dari berbagai sumber yang dikelola oleh masyarakat sendiri.

Meningkatnya kesadaran hukum masyarakat tidak seiring dengan kualitas pelayanan dan penegakan hukum serta bantuan hukum dengan biaya yang terjangkau. Hal inilah yang melahirkan kekecewaan dan mengakibatkan ketidakpercayaan masyarakat kepada aparat penegak hukum tidak kunjung surut. Kekecewaan dan ketidakpercayaan itu kadang kala dilampiaskan dengan aksi kekerasan dan tindakan yang menurunkan martabat pengadilan (contemp of court). Peningkatan budaya kepatuhan terhadap hukum di masa depan tidak hanya dapat dilakukan dengan himbauan dan sosialisasi, melainkan juga didukung dengan pelayanan dan proses hukum yang cepat, sederhana, dan murah, dan yang lebih penting lagi adalah harus ada jaminan bahwa orang yang mematuhi hukum akan mendapat keadilan dan dilindungi hak-haknya.

\section{Capaian dan Proyeksi Kondisi Hukum Indonesia}

\section{Latar Belakang Reformasi}

Untuk mengetahui capaian hukum kita pasca reformasi, tentu kita harus memiliki dasar pijak, yaitu dengan melihat terlebih dahulu apa yang dulu menyebabkan dilakukannya reformasi di bidang hukum. Artinya, masalah-masalah apa saja yang timbul dalam bidang pembangunan hukum pada masa Orde Baru sehingga kita melakukan reformasi di bidang hukum melalui reformasi politik pada tahun 1998. berikut ini adalah masalah-masalah hukum di masa lalu yang kemudian dicoba untuk diperbaiki pada era reformasi melalui reformasi hukum dan berdasarkan itu pula dapat diukur sejauh mana kita telah melangkah.

Pertama, pada masa Orde Baru, hukum kita dalam arti undang-undang bersifat elitis, bersumber dari lembaga eksekutif yang secara politik dipaksakan agar menjadi hukum. Pada waktu itu, peran DPR maupun parpol hampir tidak ada di dalam proses pembuatan hukum. Artinya, lebih bersifat formalistis. Hukum selalu disiapkan di istana kepresidenan, kemudian dibahas segi bahasa dan tata tulisnya oleh DPR, tanpa ada 
perubahan yang substantif. Selain bersifat elitis, pada masa lalu juga tercatat bahwa hukum kita bersifat positivistik-instrumentalistik. Artinya, hanya menjadi alat pembenar atas kehendak penguasa, baik yang terlanjur maupun yang akan dilakukan. Dengan watak seperti ini, seringkali hukum atau undang-undang menjadi alat untuk membenarkan kebijakan yang sebenarnya salah atau tidak baik.

Kedua, hal yang tidak dapat disembunyikan pada masa lalu adalah bahwa pengadilan kita berwatak koruptif sehingga pada saat itu popular istilah "mafia peradilan". Sebenarnya, istilah "mafia peradilan" tidak tepat di dalam dunia hukum. Istilah yang lebih tepat adalah korupsi peradilan (judicial corruption). Mafia peradilan itu ditandai oleh banyaknya korupsi dan ketidakjujuran di dalam penegakan hukum. Hal itu bisa dilakukan baik karena intervensi kekuasaan eksekutif terhadap pengadilan maupun karena kolusi di kalangan para penegak hukum sendiri. Jadi, pada waktu itu, kita sering mendengar bahwa seseorang yang punya perkara di pengadilan harus menyediakan dana tertentu untuk memudahkan urusan-urusannya. Pengurusan itu bisa dilakukan melalui permainan antara pengacara, jaksa, dan hakim. Mafia peradilan selalu tidak bisa dibuktikan secara formal tetapi bisa dirasakan sebagai judicial corruption yang menyengat di tengah masyarakat. Kalau ditanya, mana buktinya ada mafia peradilan? Jawabnya, tidak ada, karena para pelakunya adalah orang yang bekerjasama untuk saling melindungi satu sama lain. Bahkan, orang yang berusaha membongkarnya bisa dihukum melalui judicial corruption baru dengan tuduhan mencemarkan nama baik hakim, jaksa, dan polisi. Itulah yang terjadi dan dirasakan kuat pada masa lalu.

Ketiga, pada masa lalu, produk hukum dalam arti undang-undang harus diterima sebagai kebenaran yang final sehingga tidak ada satu lembaga pun yang bisa melakukan pengujian, apalagi untuk membatalkannya. Undang-undang yang dibuat oleh pemerintah dan DPR (legislatif) tidak bisa diganggu gugat meskipun di dalamnya terdapat kesalahan. Gugatan atas undng-undang waktu itu hanya bisa dilakukan melalui satu jalur, yaitu legislative review. Dengan kata lain, sebuah undang-undang hanya bisa dibatalkan oleh pembuatnya sendiri. Meskipun sebuah undang-undang sudah jelas-jelas salah, kalau DPR dan pemerintah sebagai lembaga legislatif tidak mau mengubahnya maka undang-undang itu tidak bisa berubah. Padahal dalam kenyataannya pada saat itu banyak sekali undang-undang yang bermasalah. 
Keempat, pada masa lalu banyak terjadi pelanggaran terhadap hakhak politik rakyat karena negara banyak melakukan kekerasan politik, misalnya dalam bentuk pembatasan adanya parpol yang ditentukan hanya tiga dan tidak bisa bertambah lagi betapapun ada gumpalangumpalan politik baru di tengah masyarakat yang memerlukan wadah berbentuk parpol tersendiri. Pengorganisasian tiga parpol itu pun diintervensi oleh pemerintah baik dalam menentukan pimpinan maupun mengarahkan pilihan-pilihan politiknya. Pelanggaran atas hak asasi di bidang politik pada saat itu seakan-akan stabil tetapi berantakan dan berubah dengan sangat mudah dan cepat.

Sejalan dengan kekerasan-kekerasan politik yang terjadi pada masa lalu, tampak pula bahwa pers kita terpasung, tidak memiliki kebebasan meskipun dalam bentuk kebebasan yang bertanggung jawab. Dikatakan bahwa prinsip kita adalah "pers bebas yang bertanggung jawab" tetapi sebenarnya tidak ada kebebasan bagi pers. Setiap berita yang akan dimuat selalu diiringi ancaman represi jika, misalnya, menyinggung atau melanggar garis politik yang ditetapkan oleh pemerintah, sehingga pada waktu itu ada yang disebut dengan telepon pemberitaan di mana pemimpin redaksi media massa diminta untuk tidak memberitakan hal-hal tertentu yang menurut pemerintah sensitif atau dapat menimbulkan kerawanan sosial dan politik.

\section{Langkah-langkah Reformasi}

Berdasarkan hal-hal tersebut, pembangunan di bidang hukum pada masa reformasi diarahkan pada beberapa hal yang penting.

Pertama, kita harus melakukan amandemen terhadap UUD. Amandemen UUD harus dilakukan dengan alasan bahwa selama pemerintahan Orde Lama dan Orde Baru yang dijalankan berdasarkan UUD 1945 yang asli selalu melahirkan pemerintahan otoriter. Artinya, selama pelaksanaan UUD 1945 tidak pernah muncul pemerintahan yang demokratis, sehingga dapat disimpulkan bahwa kalau mau memperbaiki kehidupan yang lebih demokratis tentu harus didahului dengan amandemen atas UUD 1945 yang asli. Tanpa ada amandemen UUD, tidak akan ada reformasi. Begitulah pandangan yang berkembang pada saat itu. Pandangan ini menjadi sangat dominan, dipikul oleh hampir semua partai politik, masyarakat kampus, LSM dan berhasil dibawa ke MPR sehingga amandemen UUD itu benar-benar dilakukan. 
Kedua, penataan lembaga peradilan melalui perubahan UU tentang Kekuasaan Kehakiman. Hal yang paling menonjol dari perubahan undang-undang tentang itu adalah bahwa agar kehakiman bisa benarbenar mandiri dan merdeka maka kekuasaan kehakiman disatuatapkan di bawah MA. Dengan begitu hakim-hakim pengadilan negeri dan pengadilan tinggi yang dulunya di bawah Menteri Kehakiman atau berada di bawah pemerintah (Departemen Pertahanan dan Departemen Agama) secara administratif dan finansial kemudian sepenuhnya berada di bawah MA.

Ketiga, sejalan dengan perubahan di bidang kekuasaan kehakiman itu juga dibentuk Komisi Pemberantasan Korupsi (KPK) sebagai lembaga alternatif untuk menerobos kesulitan-kesulitan pemberantasan korupsi di pengadilan konvensional. Indonesia membentuk KPK dengan pengadilan tersendiri, yaitu Pengadilan Tipikor yang diberi tugas khusus menangani soal-soal korupsi yang dilakukan oleh penyelenggara Negara dengan nilai korupsi 1 milyar ke atas dan/atau dengan kasus yang menarik perhatian masyarakat. Sejalan dengan itu pula dibentuk Komisi Yudisial (KY) dengan fungsi mengawasi perilaku para hakim. Karena pada masa lalu banyak mafia peradilan (judicial corruption) maka sekarang dibentuk KY sebagai lembaga Negara yang masuk di dalam UUD, yang tugasnya menyelesaikan dan mengusulkan calon hakim agung, serta mengawasi perilaku hakim untuk menjaga kehormatan dan keluhuran martabat hakim.

Lembaga baru lainnya yang juga dibentuk pada masa reformasi adalah Mahkamah Konstitusi (MK). Semula, MK dibentuk dengan dua latar belakang saja. Pertama, karena pada masa lalu tidak ada suatu lembaga yang bisa membatalkan undang-undang kecuali legislatif sendiri sehingga diperlukan satu lembaga seperti MK yang diberi wewenang untuk menguji konstitusionalitas undang-undang Kedua, MK sebenarnya dimaksud sebagai forum previligiatum atau pengadilan khusus ketatanegaraan tatkala presiden mau diberhentikan dalam masa jabatannya. Ada keinginan agar proses pemberhentian presiden pada masa jabatannya didahului dengan penilaian hukum. Dengan adanya forum previligiatum tersebut Presiden tidak cukup hanya dijatuhkan dengan alasan-alasan politik tanpa didasarkan pada alasan-alasan hukum yang bisa dinilai lebih dulu oleh pengadilan. Namun demikian, dalam perkembangannya kemudian MK selain berwenang melakukan pengujian UU terhadap UUD dan memberi penilaian hukum atau menilai dakwaan 
DPR bahwa presiden telah melakukan pelanggaran tertentu dan dapat diberhentikan dari jabatannya juga ada wewenang-wewenang lain yang diberikan kepada MK, yaitu menangani sengketa kewenangan antar lembaga negara yang kewenangannya diberikan oleh UUD, memutuskan pembentukan partai politik, dan menangani perselisihan pemilihan umum. Itulah kewenangan MK yang asli, sebagaimana tercantum dalam Pasal 7 dan Pasal 24C UUD 1945 hasil amandemen. Kemudian sejak tahun 2008 dengan keluarnya UU No. 12 tahun 2008 tentang Perubahan UU No. 32 Tahun 2004 tentang Pemerintahan Daerah kewenangan MK ditambah lagi, yaitu memutus perselisihan hasil pemilihan umum kepala daerah (Pemilukada). Berdasarkan UU No. 32 Tahun 2004 sebelum diubah, sebenarnya kewenangan mengadili perselisihan pemilihan kepala daerah ada di tangan MA. Tetapi, dengan UU No. 12 Tahun 2008, kewenangan itu dialihkan ke MK. Dasar pengalihannya adalah di dalam UU No. 22 Tahun 2007 tentang Penyelenggaraan Pemilu disebutkan bahwa pemilihan umum kepada daerah itu adalah pemilu sebagaimana dimaksud Pasal 22E UUD 1945. Oleh karena itu dimasukkan ke dalam rezim pemilu maka dengan sedirinya sengketa-sengketanya pun dianggap tepat kalau dipindahkan menjadi wewenang MK sesuai dengan ketentuan Pasal 24C UUD 1945.

\section{Hasil yang Dicapai}

Sekarang yang menjadi pertanyaan adalah, apa yang sudah kita capai dari latar belakang persoalan dan langkah-langkah yang diambil untuk mengatasi persoalan itu? Secara umum, saya ingin mengatakan bahwa dari berbagai langkah yang diambil itu ada yang mencapai tujuannya secara efektif dan ada pula yang tidak efektif. Pertama, pada saat ini, diakui atau tidak, demokrasi sudah jauh lebih hidup. Terjadi perkembangan yang positif di bidang hak-hak politik masyarakat. Masyarakat sekarang sudah bisa mengikuti pemilu dengan langsung umum bebas dan rahasi tanpa tekanan dari aparat negara. Kalaupun ada orang yang dipaksa-paksa untuk memilih salah satu partai, itu bukan oleh negara, melainkan oleh parpol atau kekuatan dalam masyarakat itu sendiri. Berbeda halnya dengan zaman dahulu di mana masyarakat dihegemoni oleh negara, bahkan disinyalir hasil pemilunya sudah diketahui jauh sebelum pemilu itu dilaksanakan karena pemerintah sudah merekayasa sebelumnya mengenai daerah mana partai apa dapat suara berapa. Sekarang praktik 
semacam itu tidak lagi terjadi. Setiap orang boleh memilih secara bebas tanpa tekanan dari siapapun. Pemilu sudah diawasi oleh lembaga-lembaga independen. Bahkan, di dalam tata politik kita sekarang, siapapun boleh mendirikan parpol sampai sebanyak-banyaknya karena hal itu merupakan hak politik masyarakat, tetapi kebebasan mendirikan parpol itu kemudian diatur dengan electoral threshold atau parliamentary threshold. Dengan demikian, setiap warga negara boleh mendirikan parpol dan boleh ikut pemilu tetapi untuk boleh terus hidup atau untuk boleh mendapat kursi di parlemen itu harus mencapai angka threshold tertentu. Ketentuan tersebut dianggap lebih fair dari pada kesempatan mendirikan parpol ditutup sama sekali. MK sudah memutuskan bahwa parliamentary threshold maupun electoral threshold adalah konstitusional.

Selain itu, masyarakat saat ini juga sudah dapat menikmati kebebasan pers. Pers boleh berekspresi, bahkan untuk mendirikan media massa, sekarang, tidak harus ada surat izin terbit (SIT) atau surat izin usaha penerbitan pers (SIUPP). Siapapun yang punya uang bisa mendirikan dan dapat menerbitkannya. Artinya, sistem politik sekarang ini sudah jauh lebih demokratis. Pada saat ini kita juga menyaksikan kemajuan yang cukup menonjol di bidang perundang-undangan karena UU sudah bisa dibatalkan melalui jalur judicial review. Padahal, dalam sistem politik sebelumnya, suatu UU hanya bisa dibatalkan melalui legislative review.

\section{Produktivitas MK}

Di sini, saya ingin memberikan tekanan pada apa yang sudah dicapai oleh MK karena selain kebetulan saya memimpin lembaga itu juga saya memang diminta menjadi pembicara untuk menjelaskan capaian pembangunan hukum kita.

Pertama, sejak didirikan pada bulan Agustus 2003, MK sudah menangani ratusan kasus dan memutuskan pula ratusan kasus. Pada pemilu 2004, sengketa hasil pemilu yang masuk ke MK ada sebanyak 479 kasus. Namun, setelah diseleksi, kasus yang memenuhi syarat sebagai perkara adalah sebanyak 274 kasus. Semua perkara sengketa hasil Pemilu 2004 bisa diselesaikan dan divonis dalam waktu yang ditentukan oleh undang-undang, yaitu 30 hari, tanpa menimbulkan persoalan-persoalan hukum baru. Memang, di dalam catatan ada dua kasus yang setelah divonis oleh MK ternyata ada kesalahan, di mana orang yang divonis

oleh MK bahwa suara yang diperolehnya benar tapi kemudian di 
pengadilan umum terbukti salah. Di sini, MK perlu menjelaskan bahwa ketika kasus itu di bawa ke MK, KPUD yang bersangkutan menerangkan bahwa hasil perhitungannya adalah benar sementara penggugat/ pemohon tidak bisa membuktikan sebaliknya. Tetapi data yang disampaikan KPUD ke MK ternyata data palsu, sementara pemohonnya tidak punya data pembanding sehingga MK menyatakan bahwa hasil pemilu yang ditetapkan oleh KPU Daerah yang bersangkutan sudah benar. Persoalannya kemudian KPUD di provinsi yang bersangkutan diadukan ke pengadilan pidana dan ternyata dia telah membuat dokumen palsu yang diajukan ke MK. Itulah yang terjadi dari 274 kasus yang ditangani MK.

Kedua, selama 5 tahun ini, MK telah menangani 178 kasus pengujian undang-undang. Suatu capaian yang luar biasa karena pada zaman Orde Lama sampai dengan Orde Baru kita tidak pernah bermimpi bisa melakukan pengujian undang-undang. Begitu MK dibentuk, dalam 5 tahun saja sudah menangani 178 pengujian undang-undang dengan perincian: yang sudah divonis 161 perkara dan 17 perkara sampai saat ini masih dalam pemeriksaan. Sebenarnya ada 206 kasus yang masuk ke MK, tetapi kemudian 28 kasus tidak diregristrasi karena tidak memenuhi syarat. Dengan kata lain, dari 206 perkara yang masuk, terdapat 178 kasus yang memenuhi syarat untuk diregistrasi dan 28 tidak registrasi. Dari 178 kasus itu perkara yang sudah divonis ada sebanyak 161 diterima sebanyak 48 perkara, ditolak 53 perkara, tidak dapat diterima sebanyak 48 perkara, dan ditarik kembali sebanyak 17 perkara. Produktivitas ini menarik untuk diketahui, sekurang-kurangnya dari sudut MK sendiri dapat dianggap sebagai kemajuan bagi capaian pembangunan hukum kita.

Ketiga, selama 5 tahun ini juga ada 11 perkara sengketa kewenangan lembaga Negara. Dari 11 perkara itu ada 2 pekara yang ditolak, 6 perkara tidak dapat diterima, dan 3 perkara ditarik oleh pemohonnya. Jadi, dalam perkara sengketa kewenangan lembga negara belum ada yang dikabulkan. Kasus terakhir adalah sengketa kewenangan antara KPU Provinsi Maluku Utara dan Presiden yang diputus tidak dapat diterima dengan alasan bahwa KPU Provinsi Maluku Utara merupakan lembaga negara tingkat daerah yang kewenangannya tidak diberikan oleh UUD, melainkan bahwa diberikan oleh UU No. 22 Tahun 2007. Oleh sebab itu, KPU Provinsi Maluku Utara dinilai tidak memiliki legal standing.

Keempat, sejak tahun 2008 MK diberi kewenangan untuk mengadili sengketa perselisihan hasil pemilihan umum kepala daerah (Pemilukada). 
Hal ini menarik karena kewenangan ini secara resmi dialihkan dari MA ke MK per 1 November 2008 tetapi sampai dengan pertengahan Januari 2009 (kira-kira 2 bulan) MK menerima perkara perselisihan hasil pemilukada itu sebanyak 27 perkara. Jadi, kalau dirata-rata, setiap 3 hari ada pemilukada dan sebagian besar dari mereka yang kalah itu berperkara.

Berdasarkan itu semua, saya mempunyai beberapa catatan. Pertama, kalau melihat pembangunan hukum atau reformasi di bidang hukum sejak 1998, saya melihat bahwa sejauh menyangkut pembangunan substansi hukum dan lembaga-lembaga hukum dan penataan lembaga dalam arti struktur organisasi lembaga penegak hukum itu sudah cukup bagus. Tetapi, tampaknya budaya hukum kita belum berubah sehingga upaya penegakan hukum belum berjalan secara efektif. Hingga saat ini banyak warga masyarakat yang berfikir bahwa kalau punya perkara selain mencari pengacara juga harus mencari uang untuk memenangkan perkara itu, bahkan, sebagai ketua MK, saya sering dihubungi orang yang menginginkan agar perkaranya dimenangkan dengan menyediakan sejumlah uang. Budaya hukum kita masih begitu karena kita sudah lama dibiasakan dengan cara seperti itu. Persoalan itu belum bisa kita selesaikan dengan baik.

Kalau dievaluasi tampaknya yang lebih efektif untuk melakukan upaya-upaya penegakan hukum adalah lembaga-lembaga baru, seperti KPK, KY, MK, bahkan juga Timtastipikor. Lembaga-lembaga itu lebih efektif dalam bekerja. Mengapa? Karena lembaga-lembaga yang baru ini tidak tersandera oleh masa lalu. Semuanya serba baru dan bisa memulai dengan cara yang baru. Oleh sebab itu, misalnya, orang-orang dari MA itu diletakkan di KPK atau di MK kontribusinya terhadap penegakan hukum itu positif. Begitu juga jaksa atau polisi yang dipekerjakan di KPK ternyata dapat berkontribusi dengan baik meskipun ketika di instansi asalnya tampak tak berdaya.

Adapun lembaga-lembaga lama sudah terlanjur tersandera oleh kerusakan-kerusakan institusional dan moral masa lalu, sehingga sekarang ini sulit memperbaiki lembaga-lembaga yang di dalamnya sudah berisi orang-orang yang terjebak pada situasi yang sebenarnya secara moral tidak bisa dipertanggungjawabkan. Karena lembaga-lembaga lama itu tersandera oleh masa lalunya, setiap akan bergerak sesuai dengan kehendak reformasi selalu terserimpung oleh situasi dalam dirinya sendiri. Itulah sebabnya, perlu waktu yang agak lama untuk memperbaiki kinerja dan membangun kepercayaan masyarakat terhadap lembaga-lembaga lama yang kelembagaannya sudah sangat kuat. 


\section{Penutup}

Berdasarkan uraian di atas dapat disimpulkan bahwa, kalau kita ingin melakukan capaian yang lebih jauh di bidang hukum, kita perlu memberikan dukungan kepada lembaga-lembaga baru agar lebih produktif. Sedangkan lembaga-lembaga lama harus ditunggu dengan lebih sabar supaya semua beban yang ada di dalamnya mengalir secara sedikit demi sedikit sampai habis. Meskipun demikian, kalau tindakan yang lebih cepat diperlukan bisa saja dilakukan misalnya melalui kebijakan amputasi atau pemutihan.

Persoalan yang sekarang juga muncul dan ini bisa mengembalikan ke situasi lama ialah bahwa reformasi politik Orde Baru yang otoriter itu semula memang menuju demokrasi, tetapi dipertengahan jalan tujuannya berubah atau berbelok lagi, memang tidak kembali ke otoriter tetapi berbelok ke oligarki, di mana keputusan-keputusan penting banyak diambil secara kolutif oleh elit-elit politik untuk kepentingan yang sempit. Ini yang harus kita awasi bersama. Kita juga telah melakukan reformasi agar hakim tidak bisa diintervensi oleh siapa pun, sehingga bebas dan mandiri di hadapan tugas-tugasnya, tetapi dalam praktik ada hakim-hakim yang justru memanfaatkan kebebasan itu secara negatif yakni menikmati kebebasan berkolusi, bukan bebas untuk melakukan fungsi peradilan secara independen dan bertanggungjawab. ${ }^{9}$ Tentu saja hal itu tidak bisa digeneralisasikan karena dalam faktanya ada juga hakim-hakim yang baik. Hanya saja, di tempat-tempat penting dan strategis itu kemudian selalu muncul aroma kolusi di dalam penegakan hukum yang biasanya kita kenal sebagai mafia peradilan.

\section{Daftar Pustaka}

Moh. Mahfud MD., Hukum dan Pilar-Pilar Demokrasi, Jakarta, Gama Media, 1999. Membangun Politik Hukum, Menegakkan Konstitusi, LP3ES, Jakarta, 2006. - Perdebatan Hukum Tata Negara Pasca Amandemen Konstitusi, Jakarta, LP3ES, 2007. , Hukum, Moral, dan Politik, Materi Stadium General untuk Matrikulasi Program Doktor Bidang Ilmu Hukum di Universitas Diponegoro, Semarang, 23 Agustus 2008.

${ }^{9}$ Moh. Mahfud MD., Hukum,..., Op.Cit., Hlm. 16. 
Inno Jamabut. “UU Mengecewakan, Ramai-Ramai Uji Materi”. Harian Sinar Harapan, 31 Desember 2008.

Ketetapan MPR Nomor X/MPR/1998 Tentang Pokok-Pokok Reformasi Pembangunan Dalam Rangka Penyelamatan Dan Normalisasi Kehidupan Nasional Sebagai Haluan Negara.

Ketetapan MPR Nomor IV/MPR/1999 Tentang Garis-Garis Besar Haluan Negara Tahun 1999 - 2004.

Peraturan Presiden Nomor 7 Tahun 2005 Tentang Rencana Pembangunan Jangka Menengah nasional Tahun 2005 - 2009.

Undang-Undang Nomor 17 Tahun 2007 Tentang Rencana Pembangunan Jangka Panjang Nasional Tahun 2005 - 2025.

Windi Widianingsih. 111 UU Tidak Pro HAM. Inilah.com. http:// www.inilah.com/berita/politik/2008/12/04/66492/111-uu-tidqk-pro-ham/ 